\title{
Optimization of Mixed Enzymolysis of Acid-exploded Poplar Wood Residues for Directional Bioconversion
}

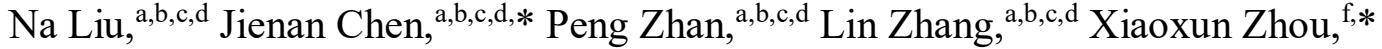 \\ Baiquan Zeng, ${ }^{\text {a,bec }}$ Zhiping Wu, ${ }^{\text {a,b,c,d }}$ and Hui Wang a,b,c
}

\begin{abstract}
Enzymolysis is a key bioconversion process of lignocellulosic biomass. The optimization of enzymolysis is important for its efficiency and accuracy. There is potential to solve the problem of low reducing sugar in the conversion of lignocellulose to bioethanol. In this study, mixed cellulases (cellulase and $\beta$-glucosidase) were used in the enzymolysis of acid-exploded poplar wood residues. The mixed enzymolysis process was optimized by response surface area test, and its kinetics model was established based on the Michaelis-Menten equation. The optimal parameters of the mixed enzymolysis were: initial, $\mathrm{pH}$ 5.2; temperature, $46{ }^{\circ} \mathrm{C}$; and cellulase to $\beta$-glucosidase ratio, 1.62 . These parameters resulted in enzymatic saccharification efficiency 1.3 times as high as that of the control (conducted with un-optimized parameters). The modeling revealed that there was a strong correlation $\left(R^{2}=0.97\right)$ between substrate concentration and reaction rate. Multiple simultaneous saccharification and cofermentation (MSSCF) developed in the laboratory was also employed to verify the optimal parameters. The mixed enzymolysis process carried out with the optimal parameters achieved an ethanol concentration of $30.09 \pm 0.49 \mathrm{~g} / \mathrm{L}$, which was 1.64 times higher than that conducted with un-optimized parameters. The fermentation time was also reduced by $24 \mathrm{~h}$. Overall, the optimization of mixed enzymolysis process could enhance the efficiency of lignocellulosic directional conversion to bioethanol.
\end{abstract}

Keywords: Lignocellulose; Ethanol; Mixed enzymolysis; Optimization; Kinetics

Contact information: a: Ministry of Forestry Bioethanol Research Center, Central South University of Forestry and Technology, Changsha, 410004, China; b: Hunan Engineering Research Center for Woody Biomass Conversion, Central South University of Forestry and Technology, Changsha, 410004, China; c: Hunan International Joint Laboratory of Woody Biomass Conversion, Central South University of Forestry and Technology, Changsha, 410004, China; d: School of Materials Science and Engineering, Central South University of Forestry and Technology, Changsha, 410004, China; e: College of Life Science and Technology, Central South University of Forestry and Technology, Changsha, 410004, China; f: College of Public Administration and Law, Hunan Agricultural University, Changsha, 410128, China;

*Corresponding authors: chenjnx@163.com; zhouxiaoxun@163.com

\section{INTRODUCTION}

Although lignocellulosic ethanol production has not yet become economical, and the high cost of enzymatic saccharification hinders its industrialization (Khare et al. 2015). Optimization of enzymolysis process, which can improve bioconversion efficiency and control accuracy, therefore plays a key role in reducing the cost of enzymatic saccharification (Ghosh et al. 2015). This has led to a number of studies that were carried out to increase cellulase activities, enhance cellulase resistance to inhibitors, and improve zymograms by optimizing the enzymolysis process (Bhutto et al. 2014; Fenila and Shastri 2016; Guo et al. 2018). Different biomasses (energy grass, bagasse, straw, eucalyptus, 
palm, etc.) and different pretreatment methods (biological, physical, chemical, and some combinations of these methods) have different effects on saccharification and inhibitors (Baboukani et al. 2012; Sun et al. 2015). Dilute acid combined with steam explosion results in higher fermentable sugar content and lower inhibitor concentration (Castro et al. 2014). In addition, pretreatment is associated with high value utilization of lignin (Narron et al. 2016; Santos et al. 2017). Although most of the research utilizes sulfuric acid, phosphoric acid can alleviate the concentration of inhibitors and reduce the cost of plant manufacturing, and fermentation residues can be used to make fertilizers (Vasconcelos et al. 2013). Hence, this study carried out mixed enzymatic optimization using dilute phosphoric acid impregnation combined with steam explosion treatment. At present, the process of bioethanol production from lignocellulose mainly can be categorized as either separate hydrolysis and fermentation (SHF), simultaneous saccharification and fermentation (SSF), or simultaneous saccharification and co-fermentation (SSCF) (Ruifei et al. 2014; Jalil et al. 2017). However, these approaches cannot save time while efficiently using lignocellulose. Therefore, the multiple simultaneous saccharification and cofermentation (MSSCF) system was selected for this work. MSSCF is able to consume reducing sugar progressively, in time to maintain a dynamic balance in an enzymatic fermentation system.

Cellulase-producing strains are mainly fungi, especially molds, of which Trichoderma, Aspergillus, and Penicillium are the main genera. Some other genera and some other fungi, bacteria, and actinomycetes can also produce cellulase (Sunil et al. 2015). Cellulase is a multi-enzyme that consists of at least three different enzyme families, namely, cellobiohydrolase $(\mathrm{CBH})$, endoglucanase $(\mathrm{EG})$, and $\beta$-glucosidase $(\beta \mathrm{G})$. These enzymes synergistically hydrolyze cellulose into reducing sugars, which are then fermented into targeted products (Zhan et al. 2017). Most commercial cellulases, including CBHs and EGs, have been produced by Trichoderma reesei (Xia et al. 2018). However, cellobiose inhibition of CBHs and EGs which is often accompanied by hydrolysis of cellulose can lead to inefficient enzymatic saccharification (Singhania et al. 2013; Velmurugan and Incharoensakdi 2016). Hence, it is highly necessary that the exogenous $\beta \mathrm{Gs}$ be supplemented into commercial cellulases to develop special mixed cellulases that prevent cellobiose inhibition (Binod et al. 2019; Zhao et al. 2018). Due to the diversity and complexity of raw materials (such as grass, softwood, hardwood, etc.), it is better to optimize enzymatic hydrolysis so that enzymatic saccharification becomes more costeffective (Van Dyk and Pletschke 2012).

The kinetics of enzymolysis are crucial to control and improve the robustness of the system. Empirical models, such as Michaelis-Menten-based, adsorption in cellulose hydrolysis, jamming, and fractal models, etc., have been employed to analyze the kinetics of enzymatic hydrolysis (Andersen et al. 2018). Michaelis-Menten models are most suitable for studying the effect of product inhibition on enzymatic saccharification. However, because these processes are complex and heterogeneous, they need further clarification.

In this study, poplar wood powder pretreated by dilute phosphoric acid-steam explosion was used as the substrate for enzymolysis by mixed cellulases (commercial cellulase appended with $\beta \mathrm{G}$ ). The enzymolysis was optimized by response surface methodology, and its kinetic model was based on the Michaelis-Menten equation to understand the relationship between substrate concentration and reaction rate. Multiple simultaneous saccharification and cofermentation (MSSCF) was conducted to evaluate its efficiency. 


\section{EXPERIMENTAL}

\section{Materials}

Poplar wood powder (diameter: 1 to $2 \mathrm{~mm}$, length: 2 to $15 \mathrm{~mm}$ ) was first soaked in $2 \mathrm{wt} \%$ dilute phosphoric acid at a solid-liquid ratio of 1:2.5 for $1 \mathrm{~h}$. The soaked powder was then treatment by a steam explosion apparatus (Hebi Zhengdao Bioenergy Co. Ltd. Hebi, Henan, China) at a pressure of $2 \mathrm{MPa}\left(20 \mathrm{bar}, 215^{\circ} \mathrm{C}\right)$ with a pressure holding time of $180 \mathrm{~s}$. The resultant samples, which was later used as substrates, were collected and stored at $4{ }^{\circ} \mathrm{C}$. The main components (cellulose, hemicellulose, lignin, and reducing sugar $[R S])$ were quantified, and the data is shown in Table 1.

Table 1. Main Components of Poplar Wood Powder

\begin{tabular}{|c|c|c|}
\hline No. & 1 & 2 \\
\hline Treatment method & Powder & $\begin{array}{c}\text { Dilute acid-steam } \\
\text { explosion powder }\end{array}$ \\
\hline Cellulose (\%) & $43.50 \pm 0.69$ & $38.19 \pm 0.51$ \\
\hline Hemicellulose (\%) & $26.20 \pm 0.57$ & $6.79 \pm 0.27$ \\
\hline Lignin (\%) & $22.31 \pm 0.34$ & $27.10 \pm 0.19$ \\
\hline Others (\%) & $4.70 \pm 0.12^{\mathrm{a}}$ & $26.80 \pm 0.33^{\mathrm{b}}$ \\
\hline RS (g/L) & - & $12.79 \pm 0.75$ \\
\hline $\begin{array}{l}\text { a Neutral washing impurities and ash } \\
\text { b Degradation products and ash } \\
\text { c Degraded reducing sugar }\end{array}$ & \\
\hline
\end{tabular}

\section{Mixed Enzymes and Strains}

Mixed enzymes were prepared by mixing $\beta \mathrm{G}$ produced in the laboratory using Aspergillus niger C112 (CCTCC M2012129) with commercial cellulase (Trichoderma) purchased from Hunan Lierkang Biological Co. Ltd. (Yueyang, Hunan Province). The selfproduced enzyme had a $\beta \mathrm{G}$ activity of $20.49 \mathrm{U} / \mathrm{mL}$ and a filter paper activity (FPA) of 1.23 $\mathrm{IU} / \mathrm{mL}$, while the mixed enzymes had a $\beta \mathrm{G}$ activity of $75.84 \mathrm{U} / \mathrm{mL}$ and a FPA of 72.34 $\mathrm{IU} / \mathrm{mL}$.

Enzyme production by Aspergillus niger C112 was carried out in $250 \mathrm{~mL}$ flasks containing $100 \mathrm{~mL}$ of culture medium at initial pH 5.0 and seed volume $6 \%$, which were cultured in the shaking table under the conditions of $200 \mathrm{r} / \mathrm{min}$ and $28^{\circ} \mathrm{C}$, for 7 days. Then the filtrate was filtered by 300 mesh molecular sieve and concentrated by TP10-20 ultrafiltration device under the operating pressure of $0.08-0.1 \mathrm{MPa}$. The enzyme solution was prepared and stored at $4{ }^{\circ} \mathrm{C}$.

Aspergillus niger $\mathrm{C} 112$ culture medium: rice straw powder $30 \mathrm{~g} / \mathrm{L}$, corncob $25 \mathrm{~g} / \mathrm{L}$, $\left(\mathrm{NH}_{4}\right)_{2} \mathrm{SO}_{4} 10 \mathrm{~g} / \mathrm{L}$, peptone $5 \mathrm{~g} / \mathrm{L}, \mathrm{KH}_{2} \mathrm{PO}_{4} 5 \mathrm{~g} / \mathrm{L}, \mathrm{CaCl}_{2} 9 \mathrm{~g} / \mathrm{L}, \mathrm{MgSO}_{4} 9 \mathrm{~g} / \mathrm{L}$, Tween 80 $1 \mathrm{ml} / \mathrm{L}, 1 \mathrm{~mol} / \mathrm{L}$ citric acid buffer $100 \mathrm{ml} / \mathrm{L}$, Mandels microelement concentrate $1 \mathrm{ml} / \mathrm{L}$. Mandels microelement concentrate formula: $\mathrm{FeSO}_{4} \cdot 7 \mathrm{H}_{2} \mathrm{O} 5 \mathrm{~g} / \mathrm{L}, \mathrm{MnSO}_{4} \cdot \mathrm{H}_{2} \mathrm{O} 1.6 \mathrm{~g} / \mathrm{L}$, $\mathrm{ZnSO}_{4} \cdot 7\left(\mathrm{H}_{2} \mathrm{O}\right) 1.4 \mathrm{~g} / \mathrm{L}, \mathrm{CoCl}_{2} \cdot 6 \mathrm{H}_{2} \mathrm{O} 3.7 \mathrm{~g} / \mathrm{L}$.

The strains used in MSSCF were Saccharomyces cerevisiae (CICC-1517RM) and recombinant Escherichia coli KO11 (ATCC-55124). Both strains were acquired from Institute of Biological and Environmental Science and Technology at Central South University of Forestry and Technology (Changsha, China). 


\section{Optimization of Enzymolysis}

The effects of different $\mathrm{pH}(4.0,4.5,5.0,5.5$, and 6.0), temperatures $(40,45,50$, 55 , and $\left.60{ }^{\circ} \mathrm{C}\right)$, substrate concentrations $(50,75,100,125$, and $150 \mathrm{~g} / \mathrm{L})$, times $(0,2,4,8$, $12,24,48$, and $72 \mathrm{~h}$ ), and ratios of $\beta \mathrm{G}$ to FPA in mixed enzymes $(1.05,1.31,1.56,1.81$, 2.04, and 16.66) on enzymolysis were studied using the single factor test. Based on the results of the test, three factors (at three different levels), including temperature, $\mathrm{pH}$, and ratios of $\beta \mathrm{G}$ to FPA were selectively subjected to response surface test (RST). All experiments were carried out in $250 \mathrm{~mL}$ flasks containing $100 \mathrm{~mL}$ of hydrolytic medium at an initial $\mathrm{pH} 5.0$, a temperature of $50^{\circ} \mathrm{C}$, a substrate concentration of $100 \mathrm{~g} / \mathrm{L}$, a time of $24 \mathrm{~h}$, and a ratio of $\beta \mathrm{G}$ to FPA (FPA loading $15 \mathrm{IU} / \mathrm{g}$ ) of 1.56 , except for the set factors.

\section{Mixed Enzymolysis Kinetics Model}

The effects of substrate concentrations $(25,50,75,100,125,150,175$, and $200 \mathrm{~g} / \mathrm{L})$ on mixed enzymolysis rate were studied based on the Michaelis-Menten kinetics model, which was then evaluated by the linearization method. The values of maximum reaction rate $\left(V_{\max }\right)$ and Michaelis-Menten constant $\left(K_{\mathrm{m}}\right)$ were confirmed and calculated by the least squares method. The adsorption capacity of substrate to protein was also determined.

\section{MSSCF}

The fermentation medium was prepared with $100 \mathrm{~g} / \mathrm{L}$ substrate, $2 \mathrm{~g} / \mathrm{L} \mathrm{KH}_{2} \mathrm{PO}_{4}, 0.4$ $\mathrm{g} / \mathrm{L} \mathrm{CaCl}_{2}, 0.4 \mathrm{~g} / \mathrm{L} \mathrm{MgSO}_{4} 7 \mathrm{H}_{2} \mathrm{O}$, and $30 \%$ (v/v) of $0.05 \mathrm{~mol} / \mathrm{L}$ citric acid buffer, pH 5.6. The temperature of the mixed enzymolysis was initially maintained under $46^{\circ} \mathrm{C}$ for $8 \mathrm{~h}$. After that, it was lowered to $37{ }^{\circ} \mathrm{C}$, the temperature at which fermentations using $S$. cerevisiae and E. coli $\mathrm{KO} 11$ at dry cell weights of $1 \mathrm{~g} / \mathrm{L}$ and $0.33 \mathrm{~g} / \mathrm{L}$, respectively, were carried out. Ethanol yield was calculated as follows.

$$
\text { Ethanol yield }=\frac{\text { Ethanol content } \times 0.9}{\text { Cellulose content } \times 0.51+\text { Hemicellul ose content } \times 0.46}
$$

where 0.9 is the conversion coefficient of glucose to cellulose; 0.51 is the conversion coefficient of glucose to ethanol; and 0.46 is the conversion coefficient of xylose to ethanol.

\section{Analysis}

The lignocellulosic components were analyzed via weight loss (Chun 2006), and the reducing sugar (RS) concentration was measured by the 3,5 dinitrosalicylic acid (DNS) method. $\beta \mathrm{G}$ activities were determined using $\mathrm{p}$-nitrophenyl- $\beta$-D-galactopyranoside (pNPG) assay, and FPA activities was determined using the DNS method (Ghose 1987). The dry weight of Saccharomyces cerevisiae and Escherichia coli KO11 were measured the absorbance value at wavelengths of $560 \mathrm{~nm}$ and $600 \mathrm{~nm}$ respectively, and the amounts were then converted into absolute dry weight of bacteria. Protein content was analyzed by Bradford assay (Sangon Biotech Limited Co. Ltd., Shanghai, China). Ethanol concentration was determined by gas chromatography (GC; GC-14C, Shimadzu, Kyoto, Japan) equipped with an FID detector and a capillary column Rtx-5. The temperatures were set as follows: inlet temperature, $180{ }^{\circ} \mathrm{C}$; detector temperature, $200{ }^{\circ} \mathrm{C}$; and column temperature, $80^{\circ} \mathrm{C}$ (Schlatter et al. 2014). 


\section{RESULTS AND DISCUSSION}

\section{Single Factor Experiment}

As shown in Fig. 1, the contents of RS produced by mixed enzymolysis were higher than those produced by single commercial enzymolysis under the same conditions, which is likely due to the synergistic effect of mixed enzyme (Chylenski et al. 2017; Wang et al. 2017). Additionally, the influence of temperatures from 40 to $45^{\circ} \mathrm{C}$ on concentration of $\mathrm{RS}$ in mixed enzymolysis was negligible compared with that in single enzymolysis, that of temperatures from 45 to $60{ }^{\circ} \mathrm{C}$ was more prominent. Furthermore, in both single and mixed enzymolysis, the concentration of RS increased with the increases of substrate concentration and reaction time (Figs. 1C, 1D), but the yield of reducing sugar decreased with the increase of substrate. Interestingly, the concentrations of RS produced under the same conditions by the two processes were not distinctly different with time under $4 \mathrm{~h}$; this is likely caused by the effects of enzyme adsorption (Machado et al. 2015) and cellobiose accumulation (Shokrkar et al. 2018).
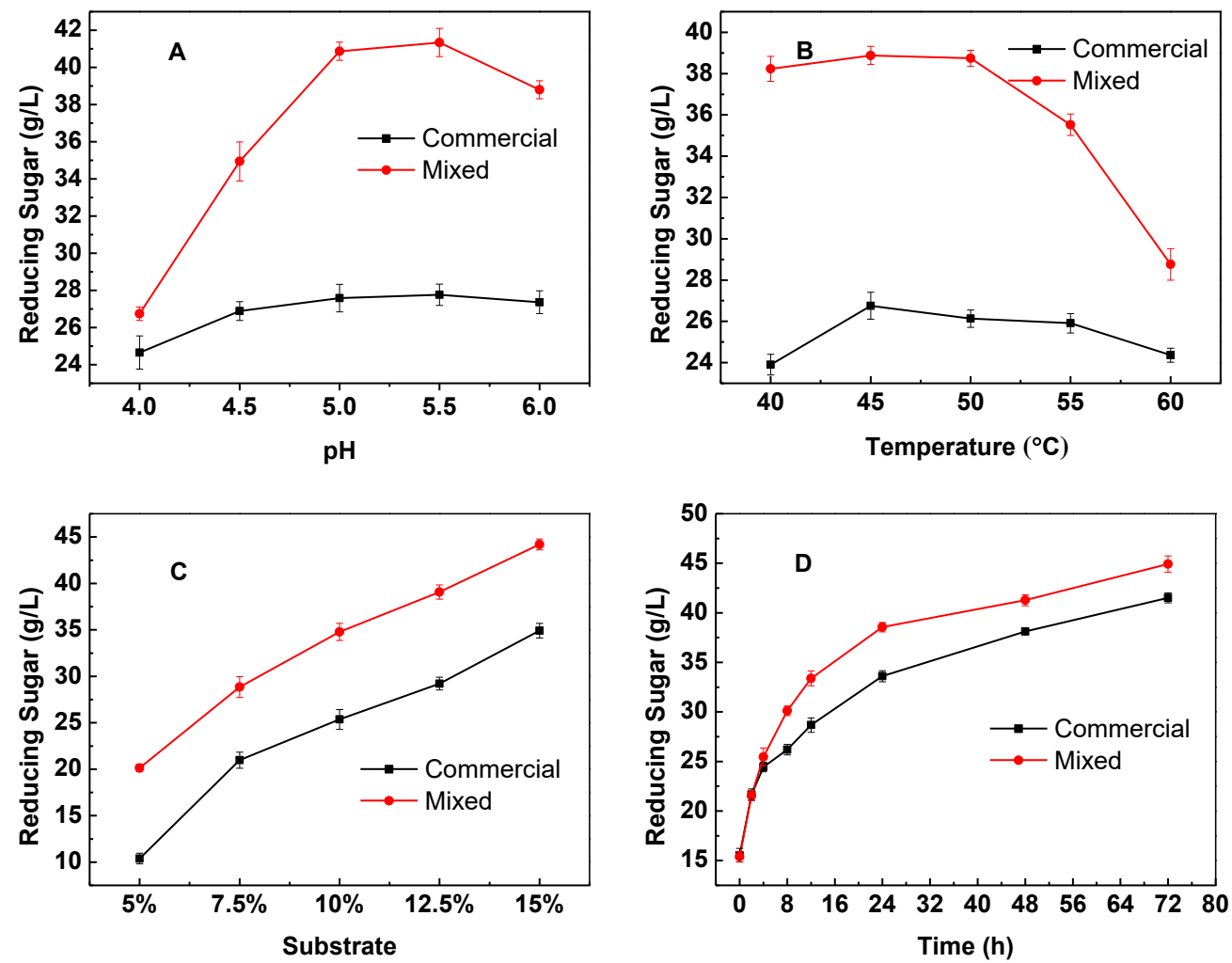

Fig. 1. Influence of different factors on RS production by commercial and mixed enzymolysis (A: $\mathrm{pH}, \mathrm{B}$ : temperature, C: substrate concentration, D: time)

As illustrated in Fig. 2, the concentration of RS increased with increasing enzyme ( $\beta \mathrm{G}$ to FPA) ratio from 1.05 to 1.56 with a maximum $\mathrm{RS}$ concentration of $42.79 \pm 0.63$ $\mathrm{g} / \mathrm{L}$; thereafter, it started to decrease at 1.81 . Moreover, the concentration of RS produced by mixed enzymolysis process was much higher than that produced by single enzymolysis process. This result indicated the mixed enzymolysis is better than the single enzymolysis. As the ratio of $\beta \mathrm{G}$ increased gradually, oligosaccharides were hydrolyzed to glucose sufficiently, and cellobiose was converted to glucose, which relieved the inhibition of 
cellobiose and promoted the increase of reducing sugar content (Shokrkar et al. 2018). When $\beta \mathrm{G}$ continually increased until the saturation was reached, the enzymatic hydrolysis efficiency started to decrease, and the reducing sugar content decreased due to the dilution of the solution.

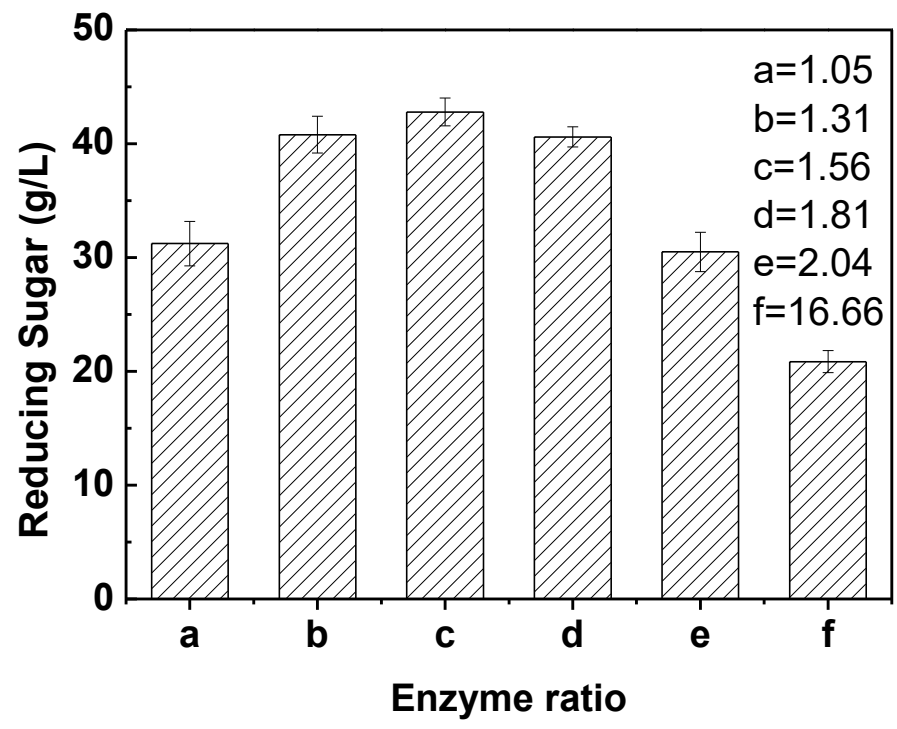

Fig. 2. Influence of different enzymes and mixed ratios on RS production (a: commercial cellulase, b-e: mixed enzymes (different $\beta G$ to FPA ratio), f: enzymes produced by $A$. niger C112).

Table 2. The Values of Factors and Results of Response Surface Test

\begin{tabular}{|c|c|c|c|c|}
\hline \multirow{2}{*}{$\begin{array}{c}\text { Run } \\
\text { no. }\end{array}$} & \multicolumn{3}{|c|}{ Factors } & Observed RS \\
\cline { 2 - 5 } & $\begin{array}{c}\mathrm{A} \\
\text { Initial pH }\end{array}$ & $\begin{array}{c}\text { B } \\
\text { Temperature } \\
\left({ }^{\circ} \mathrm{C}\right)\end{array}$ & $\begin{array}{c}\mathrm{C} \\
\text { Enzyme ratio }\end{array}$ & $(\mathrm{g} / \mathrm{L})$ \\
\hline 1 & 5.5 & 40 & 1.56 & $39.83 \pm 0.37$ \\
\hline 2 & 5.0 & 50 & 1.05 & $30.78 \pm 0.44$ \\
\hline 3 & 5.5 & 45 & 1.05 & $35.77 \pm 0.71$ \\
\hline 4 & 4.5 & 45 & 1.05 & $26.79 \pm 0.68$ \\
\hline 5 & 5.0 & 45 & 1.56 & $42.66 \pm 0.52$ \\
\hline 6 & 5.0 & 45 & 1.56 & $40.40 \pm 0.33$ \\
\hline 7 & 5.0 & 45 & 1.56 & $40.44 \pm 0.19$ \\
\hline 8 & 4.5 & 40 & 1.56 & $36.19 \pm 0.24$ \\
\hline 9 & 4.5 & 45 & 2.04 & $18.93 \pm 0.56$ \\
\hline 10 & 4.5 & 50 & 1.56 & $24.23 \pm 0.73$ \\
\hline 11 & 5.0 & 40 & 1.05 & $32.40 \pm 0.50$ \\
\hline 12 & 5.5 & 45 & 2.04 & $21.06 \pm 0.25$ \\
\hline 13 & 5.0 & 45 & 1.56 & $40.26 \pm 0.69$ \\
\hline 14 & 5.5 & 50 & 1.56 & $39.65 \pm 0.35$ \\
\hline 15 & 5.0 & 40 & 2.04 & $20.42 \pm 0.67$ \\
\hline 16 & 5.0 & 45 & 1.56 & $40.49 \pm 0.47$ \\
\hline 17 & 5.0 & 50 & 2.04 & $21.83 \pm 0.52$ \\
\hline
\end{tabular}




\section{RST Optimization}

The RST optimization results are shown in Table 2 . The model $\left(\mathrm{R}^{2}=0.974\right)$ used to simulate three factors (initial $\mathrm{pH}$ value, temperature, and enzyme ratio) is as follows.

$$
\begin{gathered}
Y=-3.30 A^{2}-2.58 B^{2}-11.91 C^{2}+2.94 A B-1.71 A C+0.75 B C+3.77 A \\
-1.54 B-5.44 C+40.85
\end{gathered}
$$

where $Y, A, B$, and $C$ represent $\mathrm{RS}$ concentration, initial $\mathrm{pH}$, temperature, and enzyme ratio, respectively.

The highest RS concentration $(42.66 \mathrm{~g} / \mathrm{L})$ was obtained at the following conditions: initial $\mathrm{pH}, 5.0$; temperature, $45^{\circ} \mathrm{C}$; and enzyme ratio, 1.56 .

Table 3 shows that the models were significantly different $(\mathrm{P}<0.0001)$. Enzyme ratio (factor $\mathrm{C}$ ) could significantly influence the production of $\mathrm{RS}$ extreme, as indicated by the $\mathrm{P}$ value of much less than 0.05 . The interaction between $\mathrm{pH}$ (factor $\mathrm{A}$ ) and temperature (factor B) could also significantly influence the RS production $(\mathrm{P}<0.05)$, while other interactions could not $(\mathrm{P}>0.05)$. Thus, the impacts of the factors on the production of RS can be ranked as follows: enzyme ratio $>$ initial $\mathrm{pH}>$ temperature.

Table 3. Significant Difference and Variance Analyses

\begin{tabular}{|c|c|c|c|c|c|}
\hline Source & Square Sum & Freedom & Mean Square & F Value & P Value \\
\hline Model & 1130.49 & 9 & 125.61 & 29.18 & $<0.0001$ \\
\hline A & 113.79 & 1 & 113.79 & 26.44 & 0.0013 \\
\hline B & 19.09 & 1 & 19.09 & 4.43 & 0.0732 \\
\hline C & 236.61 & 1 & 236.61 & 54.97 & 0.0001 \\
\hline AB & 34.68 & 1 & 34.68 & 8.06 & 0.0251 \\
\hline AC & 11.74 & 1 & 11.74 & 2.73 & 0.1426 \\
\hline BC & 2.28 & 1 & 2.28 & 0.53 & 0.4908 \\
\hline A2 & 45.73 & 1 & 45.73 & 10.62 & 0.0139 \\
\hline B2 & 27.79 & 1 & 27.79 & 6.50 & 0.0382 \\
\hline C2 & 597.73 & 1 & 597.73 & 138.88 & $<0.0001$ \\
\hline Residual & 30.13 & 7 & 4.3 & & \\
\hline Lack of Fit & 26.02 & 3 & 8.67 & 8.44 & 0.0333 \\
\hline Value & 4.11 & 4 & 1.03 & & \\
\hline Pure Error & 1160.62 & 16 & & & \\
\hline Sum & & & & \\
\hline
\end{tabular}

Three dimensional response surface and contour map (Fig. 3) were used to observe the effect of interactions between two variables on the production of RS. The elliptical shape of the contour map of initial $\mathrm{pH}$ value versus temperature indicates that the interaction between the two factors is more prominent than that between temperature and enzyme ratio, or between initial $\mathrm{pH}$ and enzyme ratio.

Simulation by Design Expert 8.0 software showed that the predicted optimal enzymolysis conditions were: initial $\mathrm{pH}, 5.2$; temperature, $46^{\circ} \mathrm{C}$; and enzyme ratio, 1.62 , with the corresponding RS concentration of $42.74 \mathrm{~g} / \mathrm{L}$. To validate the predicted optimal conditions, three replicate experiments were performed, and an average maximum $\mathrm{RS}$ concentration of $43.11 \pm 0.61 \mathrm{~g} / \mathrm{L}$ was obtained. This value is 1.3 folds higher than the value obtained from un-optimized conditions. 


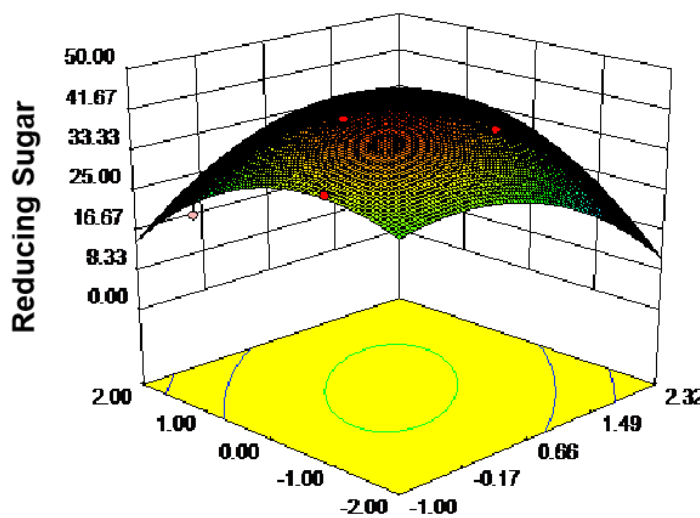

B: B

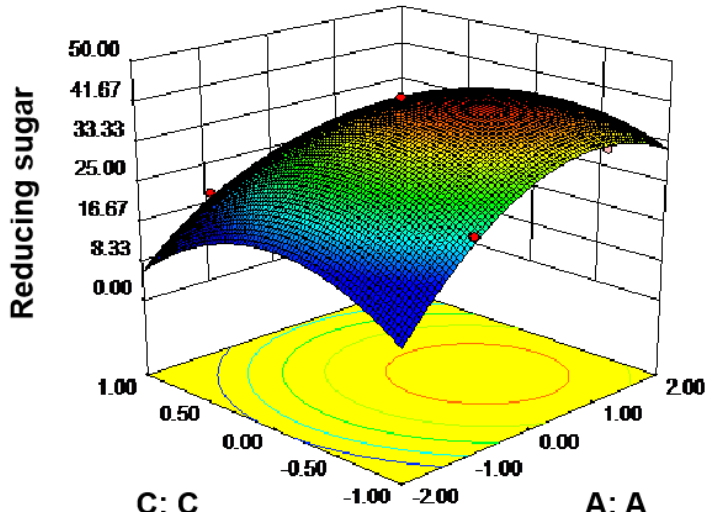

C: $\mathrm{C}$

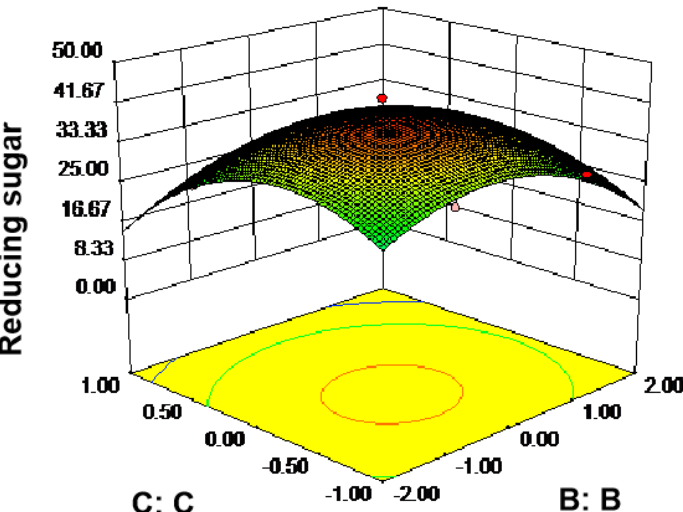

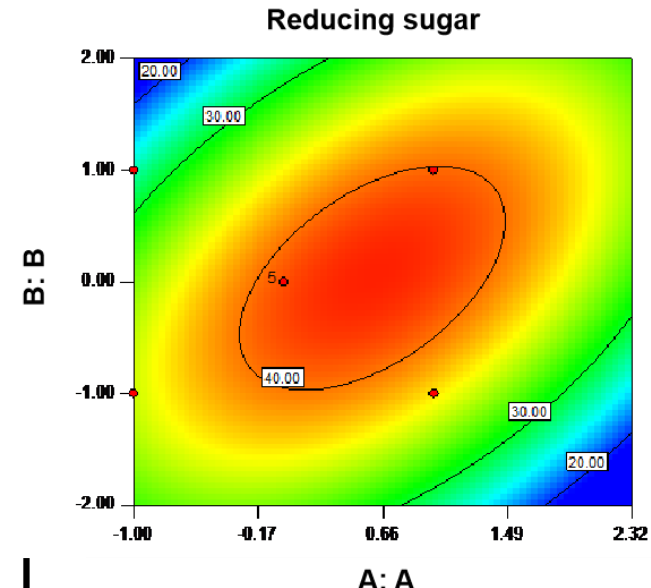

Reducing sugar

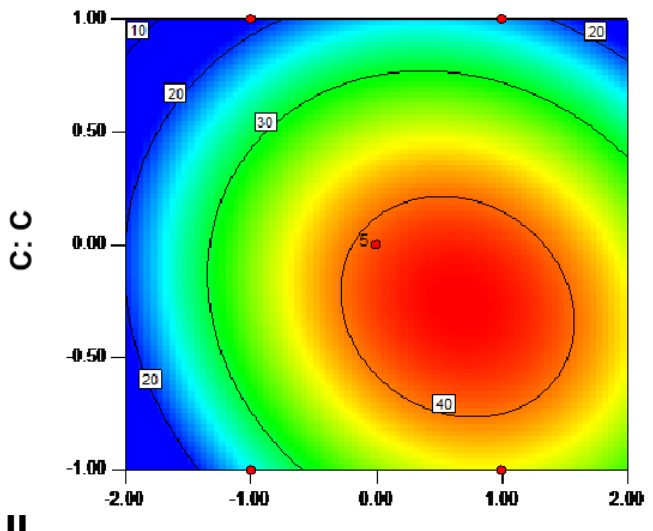

A: A

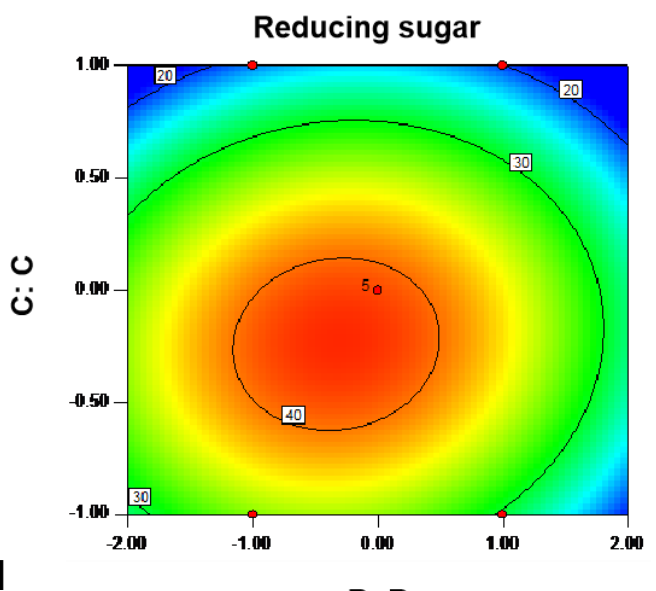

B: B

Fig. 3. Three dimensional response surface and contour map illustrating effects of interactions of different factors on enzymolysis (I: initial $\mathrm{pH}$ and temperature, II: initial $\mathrm{pH}$ and enzyme ratio, III: temperature and enzyme ratio)

\section{Kinetics Model for Mixed Enzymolysis}

The substrate type influences adsorption equilibrium time in biomass enzymolysis (Machado et al. 2015). The enzymolysis rate of different substrate concentrations at different times is shown in Fig. 4. At reaction time of lower than $3 \mathrm{~h}$, mixed enzymolysis rates were irregular, which may be caused by non-equilibrium adsorption. The equilibrium 
time of cellulase adsorbed on acid pretreated wild ryegrass is $8 \mathrm{~h}$ (Zheng 2007). In contrast, at reaction time of higher than $3 \mathrm{~h}$, mixed enzymolysis rates increased with increasing substrate concentration, but decreased with time. Because the amount of enzyme was sufficient when the concentration of substrate was low, the rate of enzymatic hydrolysis increased with the increase of the concentration of substrate. When the enzyme and substrate reached saturation, the rate of enzymatic hydrolysis was slowed by increasing the substrate concentration (more than $175 \mathrm{~g} / \mathrm{L}$ ), because the excessive substrate concentration led to ineffective adsorption and spatial hindrance of the enzyme (Pareek et al. 2013; Rahikainen et al. 2013). In addition, the substrate reduction reaction rate was relatively slowed over time as the amount of enzyme was constant.

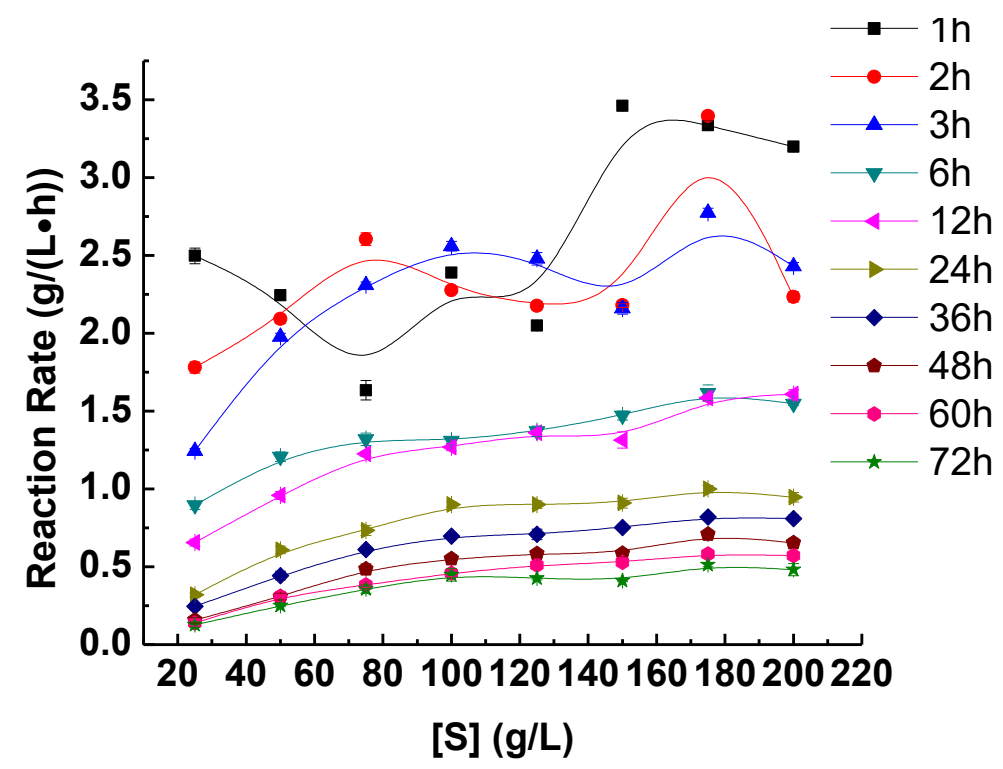

Fig. 4. Effects of substrate concentrations on enzymolysis rate (different colors represent reaction rates at different time points)

The relationship between substrate concentration and enzymolysis rate within $24 \mathrm{~h}$ was linear and conformed with the Michaelis-Menten equation (Fig. 5) with $V_{\max }=1.54$ $\left(\mathrm{g} /(\mathrm{L} \cdot \mathrm{h})\right.$ and $K_{\mathrm{m}}=89.38$.
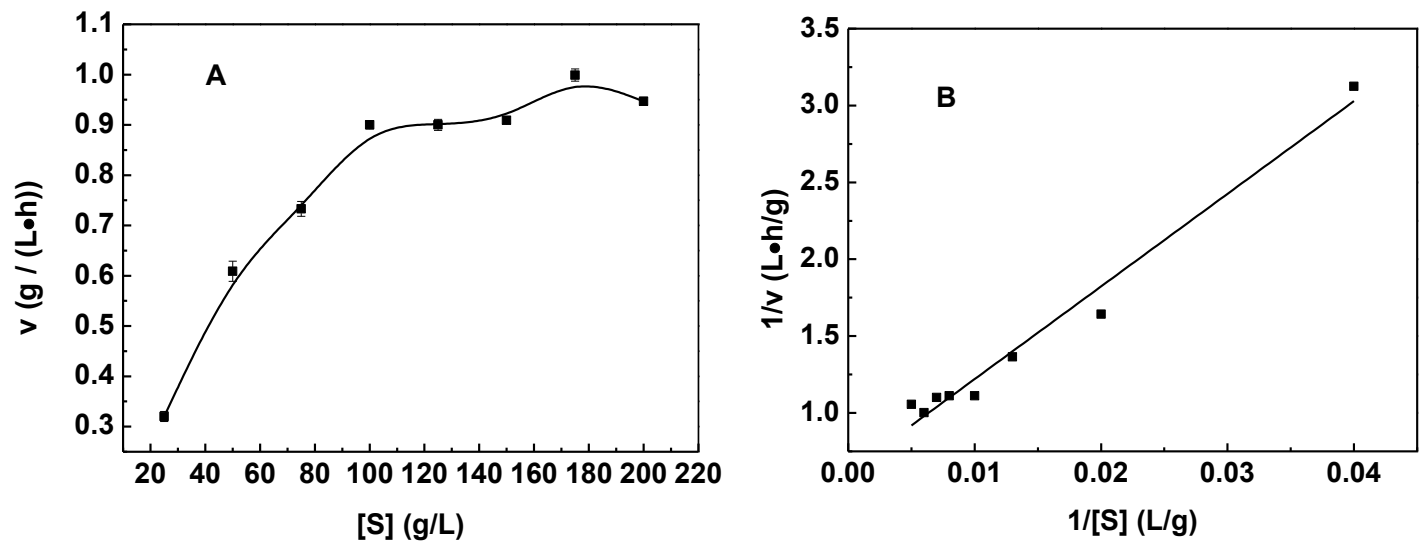

Fig. 5. Effects of substrate concentrations on enzymolysis rate within $24 \mathrm{~h}$ (A: untreated dates, B: linear expression) 
As shown in Fig. 6, the relationship between substrate concentration and protein adsorption was similar to that between substrate concentration and reaction rate with the maximum protein adsorption capacity $\left(P_{\max }\right)=1.805(\mathrm{~g} / \mathrm{L})$ and the equilibrium constant $\left(K_{\mathrm{p}}\right)=5.635$. These values indicate that protein adsorption in mixed enzymolysis is important (Lu et al. 2017).
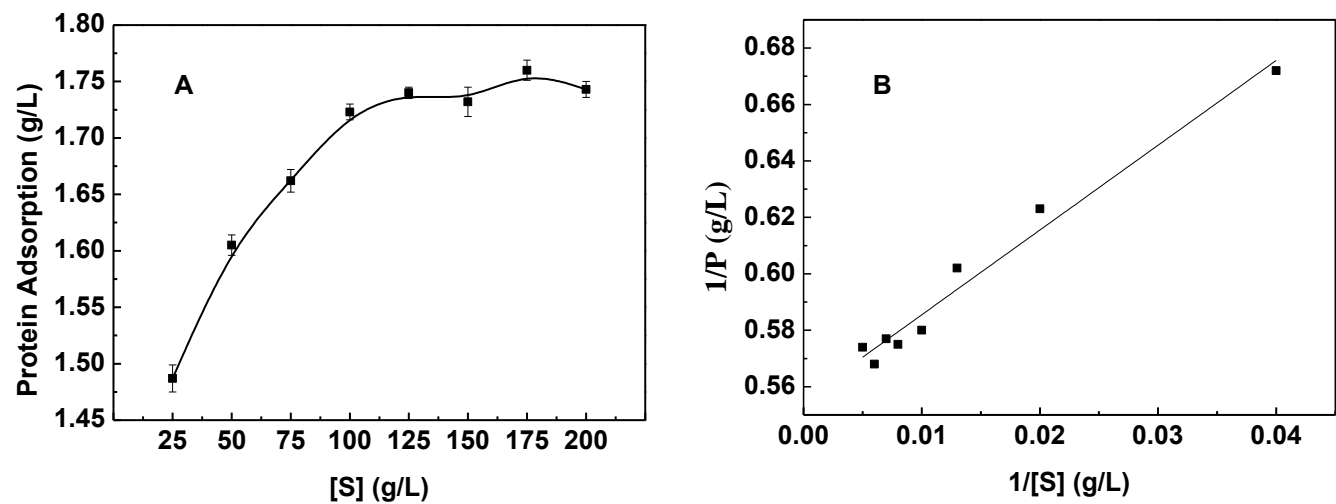

Fig. 6. Effects of substrate concentrations on protein adsorption (A: untreated dates, B: linear expression)

\section{Comparison of Effects of Commercial and Mixed Enzymolysis on Ethanol Fermentation}

Ethanol fermentation is a bilateral fermentation process. Excessive initial sugar concentration causes stress on yeast growth, but low sugar concentration directly affects ethanol production (Dengfeng 2014). By increasing the content of reducing sugar in the enzymatic hydrolysis process, combined with the process of MSSCF fermentation, reducing sugar can be consumed in time to achieve dynamic balance, which can effectively solve the bilateral effects. As shown in Fig. 7, the yields of ethanol produced using commercial and mixed enzymolysis in MSSCF system for $72 \mathrm{~h}$ were $18.77 \pm 0.38$ and $30.78 \pm 0.49 \mathrm{~g} / \mathrm{L}$, respectively, which correspond with theoretical conversion rates of $49.34 \%$ and $80.91 \%$, respectively.
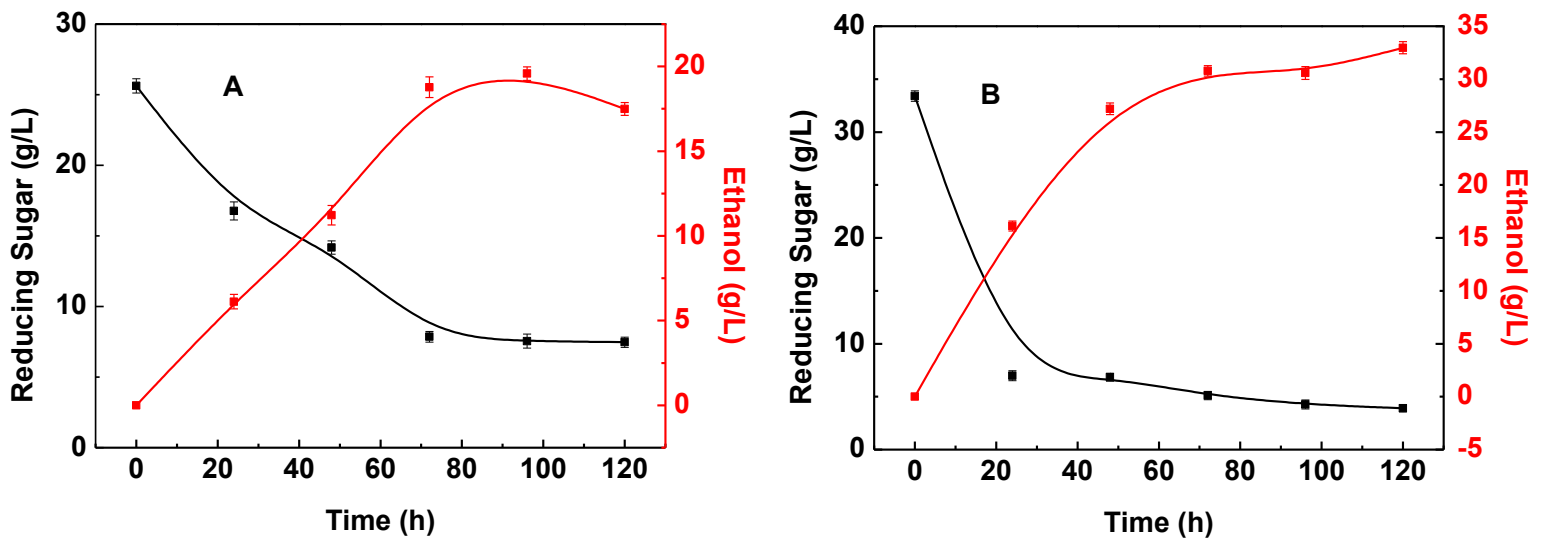

Fig. 7. Comparison of single and mixed enzymolysis carried out in MSSCF (A: commercial enzyme, B: mixed enzyme, the black line is the reducing sugar concentration and the red line is the ethanol concentration) 
Furthermore, at about $24 \mathrm{~h}$, the rate of RS consumption was faster, and the yield of ethanol in mixed enzymolysis was higher than in commercial enzymolysis. Because the addition of $\beta$-glucosidase, compared with commercial enzyme mixtures, can convert oligosaccharides (cellobiose) into reducing sugars in a more timely and sufficient manner for fermentation strains to convert to ethanol.

Pretreatment, enzymolysis, and fermentation are the main processes of ethanol fermentation of lignocellulosic, and they interact with each other. In order to achieve higher ethanol yield, the three should be highly coordinated and unified.

The enzymatic hydrolysis process serves as a bridge that links pretreatment and fermentation. This is because enzymatic hydrolysis is not only a verification of the pretreatment effect of the material, but also a direct factor affecting the fermentation effect. Efficiently connecting the pretreatment and fermentation process to save time and cost is a problem that needs to be solved. First, poplar wood residues were pretreated by dilute phosphoric acid steam explosion; the resulting pulp had increased accessibility of substrates, which promotes enzymatic hydrolysis. Most hemicellulose was degraded to reducing sugar but cellulose and lignin remained almost unchanged. Therefore, it was necessary to promote the degradation of cellulose into reducing sugar to ferment ethanol through the process of subsequent enzymatic hydrolysis. In addition, phosphorus is beneficial to sugar metabolism. It can promote the growth and reproduction of microorganisms, and may promote the subsequent fermentation experiments. The enzymatic hydrolysis process was optimized under mixed enzymatic hydrolysis conditions to improve conversion efficiency and accuracy. Furthermore, combined with the process of MSSCF, this work also can effectively solve the bilateral effects. In general, all processes are effectively combined for promoting efficient conversion of residues into bioethanol.

\section{CONCLUSIONS}

1. Mixed enzymolysis of dilute phosphoric acid-steam exploded poplar wood residues was optimized using response surface experimental design and analysis. The optimal enzymolysis conditions were: initial $\mathrm{pH}, 5.2$; temperature, $46{ }^{\circ} \mathrm{C}$; and enzyme ratio, 1.62 .

2. The parameters for the kinetics model was analyzed based on the Michaelis-Menten equation, and the enzyme had $V_{\max }=1.54 \mathrm{~g} / \mathrm{L} \cdot \mathrm{h}$ and $K_{\mathrm{m}}=89.38$.

3. Multiple simultaneous saccharification and cofermentation (MSSCF) was developed in the laboratory to verify the obtained optimal conditions. The mixed enzyme resulted in the highest ethanol production of $30.78 \pm 0.49 \mathrm{~g} / \mathrm{L}$ with a theoretical yield of $80.91 \%$, which was 1.64 times as high as the production by un-optimized conditions.

\section{ACKNOWLEDGMENTS}

The authors are grateful for the support provided by the National Key Research and Development Program of China (Grant No. 2018YFD0600302), the Key Research and Development Program of Hunan Province (Grant No. 2017NK1010), the Natural Science 
Foundation of Hunan Province (Grant No. 2017JJ2412), and the Science and Technology Plan Project of Hunan Province (Grant No. 2017WK2022).

\section{REFERENCES CITED}

Andersen, M., Kari, J., Borch, K., and Westh, P. (2018). "Michaelis - Menten equation for degradation of insoluble substrate," Mathematical Biosciences 296, 93-97. DOI: 10.1016/j.mbs.2017.11.011

Baboukani, B. S., Vossoughi, M., and Alemzadeh, I. (2012). "Optimisation of dilute-acid pretreatment conditions for enhancement sugar recovery and enzymatic hydrolysis of wheat straw," Biosystems Engineering 111(2), 166-174. DOI:

10.1016/j.biosystemseng.2011.11.009

Bhutto, A. W., Quraishi, K., Harijan, K., Zahedi, G., and Bahadori, A. (2014). "Strategy for consolidation of biologically mediated events in conversion of pre-treated lignocellulose into ethanol," RSC Advances 4(7), 3392-3412. DOI: 10.1039/C3RA44020F

Binod, P., Gnansounou, E., Sindhu, R., and Pandey, A. (2019). "Enzymes for second generation biofuels: Recent developments and future perspectives," Bioresource Technology Reports 5, 317-325. DOI: 10.1016/j.biteb.2018.06.005

Castro, E., Nieves, I. U., Mullinnix, M. T., Sagues, W. J., Hoffman, R. W., FernándezSandoval, M. T., Tian, Z., Rockwood, D. L., Tamang, B., and Ingram, L. O. (2014). "Optimization of dilute-phosphoric-acid steam pretreatment of Eucalyptus benthamii for biofuel production," Applied Energy 125, 76-83. DOI: 10.1016/j.apenergy.2014.03.047

Chun, C. (2006). Study on Preparation of Novel Platform Compound Levulinic Acid from Biomass, Ph.D. Dissertation, Zhejiang University, Hangzhou, China.

Chylenski, P., Forsberg, Z., Ståhlberg, J., Várnai, A., Lersch, M., Bengtsson, O., Seb, S., Horn, S. J., and Eijsink, V. G. (2017). "Development of minimal enzyme cocktails for hydrolysis of sulfite-pulped lignocellulosic biomass," Journal of Biotechnology 246, 16-23. DOI: 10.1016/j.jbiotec.2017.02.009

Dengfeng, L. (2014). Modeling and Optimization of the Rice Wine Fermentation Process, Ph.D. Dissertation, Jiangnan University, Wuxi, China.

Fenila, F., and Shastri, Y. (2016). "Optimal control of enzymatic hydrolysis of lignocellulosic biomass," Resource-Efficient Technologies 2, S96-S104. DOI: 10.1016/j.reffit.2016.11.006

Ghose, T. K. (1987). "Measurement of cellulase activities," Pure and Applied Chemistry 59(2), 257-268. DOI: 10.1351/pac198759020257

Ghosh, D., Dasgupta, D., Agrawal, D., Kaul, S., Adhikari, D. K., Kurmi, A. K., Arya, P. K., Bangwal, D., and Negi, M. S. (2015). "Fuels and chemicals from lignocellulosic biomass: an integrated biorefinery approach," Energy \& Fuels 29(5), 3149-3157. DOI: 10.1021/acs.energyfuels.5b00144

Guo, H., Chang, Y., and Lee, D. J. (2018). "Enzymatic saccharification of lignocellulosic biorefinery: Research focuses,” Bioresource Technology 252, 198-215. DOI: 10.1016/j.biortech.2017.12.062

Jalil, S., Faisal, K., Yan, Z. (2017). "Kinetic modeling and dynamic analysis of simultaneous saccharification and fermentation of cellulose to bioethanol," Energy Conversion and Management 141, 236-243. DOI: 10.1016/j. enconman. 2016.08.025 
Khare, S. K., Pandey, A., and Larroche, C. (2015). "Current perspectives in enzymatic saccharification of lignocellulosic biomass," Biochemical Engineering Journal 102, 38-44. DOI: 10.1016/j.bej.2015.02.033

Lu, X., Wang, C., Li, X., Zhao, J., and Zhao, X. (2017). "Studying nonproductive adsorption ability and binding approach of cellobiohydrolase to lignin during bioconversion of lignocellulose," Energy \& Fuels 31(12), 14393-14400. DOI: 10.1021/acs.energyfuels.7b02427

Machado, D. L., Moreira Neto, J., da Cruz Pradella, J. G., Bonomi, A., Rabelo, S. C., and da Costa, A. C. (2015). "Adsorption characteristics of cellulase and $\beta$-glucosidase on Avicel, pretreated sugarcane bagasse, and lignin," Biotechnology and Applied Biochemistry 62(5), 681-689. DOI: 10.1002/bab.1307

Narron, R. H., Kim, H., Chang, H. M., Jameel, H., and Park, S. (2016). "Biomass pretreatments capable of enabling lignin valorization in a biorefinery process," Current Opinion in Biotechnology 38, 39-46," DOI: 10.1016/j.copbio.2015.12.018

Pareek, N., Gillgren, T., and Jönsson, L. J. (2013). "Adsorption of proteins involved in hydrolysis of lignocellulose on lignins and hemicelluloses," Bioresource Technology 148, 70-77. DOI: 10.1016/j.biortech.2013.08.121

Rahikainen, J. L., Martin-Sampedro, R., Heikkinen, H., Rovio, S., Marjamaa, K., Tamminen, T., and Kruus, K. (2013). "Inhibitory effect of lignin during cellulose bioconversion: The effect of lignin chemistry on non-productive enzyme adsorption," Bioresource Technology 133, 270-278. DOI: 10.1016/j.biortech.2013.01.075

Ruifei, W., Rakesh, K., Lisbeth, O., and Carl, J. F. (2014). "Kinetic modeling of multifeed simultaneous saccharification and co-fermentation of pretreated birch to ethanol" Bioresource Technology 172, 303-311. DOI: 10.1016/j.biortech.2014.09.028

Santos, J. I., Fillat, Ú., Martín-Sampedro, R., Eugenio, M. E., Negro, M. J., Ballesteros, I., Rodriguez, A., and Ibarra, D. (2017). "Evaluation of lignins from side-streams generated in an olive tree pruning-based biorefinery: Bioethanol production and alkaline pulping," International Journal of Biological Macromolecules 105, 238-251. DOI: 10.1016/j.ijbiomac.2017.07.030

Schlatter, J., Chiadmi, F., Gandon, V., and Chariot, P. (2014). "Simultaneous determination of methanol, acetaldehyde, acetone, and ethanol in human blood by gas chromatography with flame ionization detection," Human \& Experimental Toxicology 33(1), 74-80. DOI: 10.1177/0960327113482845

Shokrkar, H., Ebrahimi, S., and Zamani, M. (2018). "Enzymatic hydrolysis of microalgal cellulose for bioethanol production, modeling and sensitivity analysis," Fuel 228, 3038. DOI: 10.1016/j.fuel.2018.04.143

Singhania, R. R., Patel, A. K., Sukumaran, R. K., Larroche, C., and Pandey, A. (2013). "Role and significance of beta-glucosidases in the hydrolysis of cellulose for bioethanol production," Bioresource Technology 127, 500-507. DOI:

10.1016/j.biortech.2012.09.012

Sun, S., Sun, S., Cao, X., and Sun, R. (2016). "The role of pretreatment in improving the enzymatic hydrolysis of lignocellulosic materials," Bioresource Technology 199, 4958. DOI: 10.1016/j.biortech.2015.08.061

Sunil, K., Ashok, P., Christian, L. (2015). "Current perspectives in enzymatic saccharification of lignocellulosic biomass," Biochemical Engineering Journal 102, 38-44. DOI: 10.1016/j.bej.2015.02.033

Van Dyk, J. S., and Pletschke, B. I. (2012). “A review of lignocellulose bioconversion using enzymatic hydrolysis and synergistic cooperation between enzymes-Factors 
affecting enzymes, conversion and synergy," Biotechnology Advances 30(6), 14581480. DOI: 10.1016/j.biotechadv.2012.03.002

Vasconcelos, S. M. D., Santos, A. M. P., Rocha, G. J. M., and Souto-Maior, A. M. (2013). "Diluted phosphoric acid pretreatment for production of fermentable sugars in a sugarcane-based biorefinery," Bioresource Technology 135, 46-52. DOI: 10.1016/j.biortech.2012.10.083

Velmurugan, R., and Incharoensakdi, A. (2016). "Proper ultrasound treatment increases ethanol production from simultaneous saccharification and fermentation of sugarcane bagasse," RSC Advances 6(94), 91409-91419. DOI: 10.1039/C6RA17792A

Wang, S. Z., Zhang, Y. H., Ren, H., Wang, Y. L., Jiang, W., and Fang, B. S. (2017). "Strategies and perspectives of assembling multi-enzyme systems," Critical Reviews in Biotechnology 37(8), 1024-1037. DOI: 10.1080/07388551.2017.1303803

Xia, Y., Yang, L., and Xia, L. (2018). "High-level production of a fungal $\beta$-glucosidase with application potentials in the cost-effective production of Trichoderma reesei cellulase," Process Biochemistry 70, 55-60. DOI: 10.1016/j.procbio.2018.03.031

Zhan, P., Sun, J., Wang, F., Zhang, L., and Chen, J. (2017). "Process optimization of $\beta$ glucosidase production by a mutant strain, Aspergillus niger C112," BioResources 12(4), 8937-8952. DOI: 10.15376/biore.12.4.8937-8952

Zhao, C., Deng, L., and Fang, H. (2018). "Mixed culture of recombinant Trichoderma reesei and Aspergillus niger for cellulase production to increase the cellulose degrading capability," Biomass and Bioenergy 112, 93-98. DOI: 10.1016/j.biombioe.2018.03.001

Zheng, Y. (2007). Kinetic Modeling of Enzymatic Saccharification and Particleboard Characteristics of Saline Biomass, Ph.D. Dissertation, University of California, Davis, USA.

Article submitted: October 15, 2019; Peer review completed: January 14, 2020; Revised version received: January 23, 2020; Accepted: January 27, 2020; Published: January 30, 2020.

DOI: 10.15376/biores.15.1.1945-1958 